\title{
A multiplex nested PCR for the detection and identification of Candida species in blood samples of critically ill paediatric patients
}

\author{
Cleison Ledesma Taira', Thelma Suely Okay², Artur Figueiredo Delgado ${ }^{3}$, Maria Esther Jurfest Rivero Ceccon ${ }^{3}$,
} Margarete Teresa Gottardo de Almeida ${ }^{4}$ and Gilda Maria Barbaro Del Negro ${ }^{1 *}$

\begin{abstract}
Background: Nosocomial candidaemia is associated with high mortality rates in critically ill paediatric patients; thus, the early detection and identification of the infectious agent is crucial for successful medical intervention. The PCR-based techniques have significantly increased the detection of Candida species in bloodstream infections. In this study, a multiplex nested PCR approach was developed for candidaemia detection in neonatal and paediatric intensive care patients.

Methods: DNA samples from the blood of 54 neonates and children hospitalised in intensive care units with suspected candidaemia were evaluated by multiplex nested PCR with specific primers designed to identify seven Candida species, and the results were compared with those obtained from blood cultures.

Results: The multiplex nested PCR had a detection limit of four Candida genomes $/ \mathrm{mL}$ of blood for all Candida species. Blood cultures were positive in $14.8 \%$ of patients, whereas the multiplex nested PCR was positive in $24.0 \%$ of patients, including all culture-positive patients. The results obtained with the molecular technique were available within 24 hours, and the assay was able to identify Candida species with 100\% of concordance with blood cultures. Additionally, the multiplex nested PCR detected dual candidaemia in three patients.

Conclusions: Our proposed PCR method may represent an effective tool for the detection and identification of Candida species in the context of candidaemia diagnosis in children, showing highly sensitive detection and the ability to identify the major species involved in this infection.
\end{abstract}

Keywords: Candidaemia, Candida spp, Multiplex PCR, ICU, Paediatric, Diagnosis

\section{Background}

Candida is the main etiological agent of nosocomial opportunistic mycoses worldwide and is associated with high mortality rates, especially in patients with underlying diseases $[1,2]$. Candida species are the third most common pathogen isolated from bloodstream infections of preterm infants and the fourth most common pathogen in paediatric intensive care unit (ICU) patients [3-5]. The incidence of invasive candidiasis among critically ill

\footnotetext{
* Correspondence: gildamdn@usp.br

'Laboratory of Medical Mycology (LIM-53), Clinical Dermartology Division, Hospital das Clínicas da Faculdade de Medicina da Universidade de São

Paulo (HCFMUSP) and Instituto de Medicina Tropical da Universidade de São Paulo (IMT-USP), Av. Dr. Enéas Carvalho de Aguiar, 500, Andar térreo, Predio 2, CEP, 05403-900 São Paulo, SP, Brazil

Full list of author information is available at the end of the article
}

paediatric patients has increased during the last two decades, and the outcome of Candida infections is particularly poor in very low birth weight infants due to central nervous system involvement, leading to neurodevelopmental impairment [6].

Candida albicans is the most frequent cause of candidaemia in paediatric patients, followed by $C$. parapsilosis in neonates. Candida tropicalis has been frequently reported in bloodstream infections of neonates and children in Latin America and some regions of southern Asia $[7,8]$.

Some groups of paediatric patients are especially predisposed to candidaemia, including preterm infants, children with haematological malignancies, stem cell and solid organ transplant recipients, children requiring a 
prolonged hospital stay in the ICU, and children undergoing medium or large surgeries. There are also risk factors associated with candidaemia, such as the use of central venous or arterial catheters, broad-spectrum antibiotics, and parenteral nutrition $[3,5]$.

The gold standard of laboratory diagnosis remains the isolation of Candida species by blood culture. However, the sensitivity of blood cultures is approximately 50\%, and the collection of small blood volumes in neonates and young children further decreases this sensitivity [9]. In addition, a time period of 48 to 96 hours is required for the identification of Candida species by blood culture [10]; thus, faster detection of Candida spp. in the blood would expedite the initiation of treatment, improving the prognosis of patients [11]. In an attempt to shorten the time required for detection of candidaemia, several groups have developed non-culture methods based on the polymerase chain reaction (PCR), which has proved to be highly sensitive and specific for the detection of Candida DNA in the blood samples of at-risk patients $[12,13]$. In addition, multiplex PCR designed to detect different targets simultaneously is time-saving and more cost-effective than the standard PCR $[10,14]$.

This study aimed to develop a multiplex nested PCR method to detect and identify seven Candida species in peripheral blood samples of critically ill paediatric patients presenting with predisposing conditions/risk factors for the development of candidaemia. The results of PCR were compared with those of blood cultures.

\section{Methods}

\section{Patients and blood samples}

This research was approved by the human research ethics committee of our institutions [Comissão de Ética para Análise de Projetos de Pesquisa do Hospital das Clínicas da FMUSP, São Paulo, SP, Brazil and Comitê de Ética em Pesquisa da FAMERP, São José do Rio Preto, SP, Brazil].

This prospective study enrolled 54 consecutive paediatric patients, among whom there were 24 neonates, admitted to the ICU of two paediatric referral hospitals in São Paulo State, Brazil. The patients presented with systemic inflammatory response syndrome (SIRS) according to the International Pediatric Sepsis Consensus [15] and at least two predisposing conditions/risk factors for the development of candidaemia.

The control group included 28 children from the Pediatric Surgery Division of the Instituto da CriançaHCFMUSP that had no evidence of any type of bloodstream infection and had undergone minor surgical procedures during the same time. The number of studied cases and controls was determined based on the 18month period set for the completion of the research (convenience sample).
Although all the patients had central catheters, blood samples for use in cultures and multiplex nested PCR were collected from a peripheral vein after written consent was obtained from parents or legal guardians.

\section{Blood cultures and phenotypic identification of Candida isolates}

Cultures were obtained aseptically by inoculating 1-2 mL of blood samples into Bactec Peds Plus/F bottles (Becton Dickinson, Franklin Lakes, NJ, USA), which were incubated in a Bactec ${ }^{\text {Tx }} 9240$ analyser (Becton Dickinson). The organisms obtained from positive cultures were identified using the $V^{2}{ }^{\circ}{ }^{\circ} 2$ system (BioMérieux, Marcy-l'Etoile, France). Blood cultures were not performed for members of the control group due to the absence of a clinical indication for this exam.

\section{DNA extractions and PCR to amplify the $\beta$-actin gene}

DNA extractions were performed according to the techniques described by Löeffler et al. [16] with modifications. Briefly, $10 \mathrm{~mL}$ of blood lysis solution was added to $1-2 \mathrm{~mL}$ of blood sample, and the mixture was centrifuged for 15 minutes at $2190 \times g$. Nucleo lysis solution $(1 \mathrm{~mL})$ was added to the cell pellet, and the solutions were homogenised. Recombinant lyticase (L-2524, Sigma-Aldrich, St. Louis, MO, USA) at $250 \mathrm{U} / \mathrm{mL}$ and $2 \% \beta$-mercaptoethanol (Merck, Darmstadt, Germany) were added, and the tubes were maintained at $37^{\circ} \mathrm{C}$ for 2 hours. The tubes were then centrifuged for 20 minutes at $15,300 \times g$ and the supernatant was transferred to clean tubes. The remaining steps were performed with the QIAamp DNA mini kit (QIAGEN, Hilden, Germany) according to the manufacturer's instructions. Then, the 54 DNA samples were amplified using a pair of human $\beta$-actin gene primers to ensure the integrity of the DNA and the absence of amplification inhibitors.

\section{Candida prototype strains}

DNA was extracted from seven Candida prototype strains (C. albicans ATCC18804, C. glabrata ATCC2001, C. parapsilosis ATCC22019, C. tropicalis ATCC 200956, C. krusei ATCC6258, C. lusitaniae ATCC66035, and C. pelliculosa ATCC8168) using a previously described method [17], and these samples were used as positive controls.

\section{PCR primers}

The fungus-specific universal oligonucleotides ITS1 and ITS4 [18] were used as outer primers. In the second amplification, the previously described inner primers for C. albicans, C. glabrata, C. parapsilosis complex, C. tropicalis, and C. krusei were used $[18,19]$. The primers for C. lusitaniae and C. pelliculosa were designed with the PrimerQuestSM and Primer-BLAST tools. The primer sequences are listed in Table 1. 
Table 1 Primers employed in the nested multiplex PCR amplifications

\begin{tabular}{|c|c|c|c|}
\hline Primers & Sequences $\left(5^{\prime} \rightarrow 3^{\prime}\right)$ & Amplicons & References \\
\hline \multirow[t]{2}{*}{ ITS $1 / 4$} & F- TCCGTAGGTGAACCTGCGG & Variable & {$[18]$} \\
\hline & R- TCCTCCGCTTATTGATATGC & & \\
\hline \multirow[t]{2}{*}{ CALB $1 / 2$} & F- TTTATCAACTTGTCACACCAGA & 272 bp & [18] \\
\hline & R- ATCCCGCCTTACCACTACCG & & \\
\hline \multirow[t]{2}{*}{ CGL 1/2 } & F- TTATCACACGACTCGACACT & $423 \mathrm{bp}$ & [18] \\
\hline & R- CCCACATACTGATATGGCCTACAA & & \\
\hline \multirow[t]{2}{*}{ CTR $1 / 2$} & F- CAATCCTACCGCCAGAGGTTAT & $357 \mathrm{bp}$ & [18] \\
\hline & R- TGGCCACTAGCAAAATAAGCGT & & \\
\hline \multirow[t]{2}{*}{ CPAR 3/2 } & F- GCCAGAGATTAAACTCAACCAA & $297 \mathrm{bp}$ & [18] \\
\hline & R- CCTATCCATTAGTTTATACTCCGC & & \\
\hline \multirow[t]{2}{*}{ CKR 2/3 } & F- ACTACACTGCGTGAGCGGAA & 362 bp & [19] \\
\hline & R- ACTACACTGCGTGAGCGGAA & & \\
\hline \multirow[t]{2}{*}{ CLU $1 / 2$} & F- GCGATACGTAGTATGACTTGCAG & $137 \mathrm{bp}$ & * \\
\hline & R- GATATTTCGGAGCAACGCCTAACC & & \\
\hline \multirow[t]{2}{*}{ CPEL 1/2 } & F-GAACTTGCTTTGGGTGGTGAG & $160 \mathrm{bp}$ & * \\
\hline & R- CTTCATCGTTGCGAGAACCAAG & & \\
\hline
\end{tabular}

$\mathrm{F}=$ forward; $\mathrm{R}=$ reverse; $\mathrm{CALB}=\mathrm{C}$. albicans; $\mathrm{CGL}=\mathrm{C}$. glabrata; $\mathrm{CTR}=\mathrm{C}$. tropicalis; $\mathrm{CPAR}=\mathrm{C}$. parapsilosis complex; $\mathrm{CKR}=\mathrm{C}$. $k$ rusei; $\mathrm{CLU}=\mathrm{C}$. lusitaniae; $\mathrm{CPEL}=$ C. pelliculosa.

* = primers designed in the current study; $\mathrm{bp}=$ base pairs.

\section{Multiplex nested PCR and detection of amplification products}

To avoid carryover contamination of the assays, reaction mixes, DNA extractions and amplifications were set up in separate rooms equipped with safety cabinets [20].

The first round of amplification was carried out in a $25 \mu \mathrm{L}$ reaction mixture containing $1 \times$ PCR buffer (Invitrogen, Carlsbad, CA, USA), $200 \mu \mathrm{M}$ dNTP (GE Healthcare, Buckinghamshire, UK), $1.5 \mathrm{mM} \mathrm{MgCl}_{2}, 0.2 \mu \mathrm{M}$ each primer (ITS1 and ITS4), 1.25 U Platinum Taq DNA polymerase (Invitrogen), and $50 \mathrm{ng}$ of genomic DNA from blood samples, which served as the DNA template. The PCR cycling conditions were as follows: an initial denaturation step of $5 \mathrm{~min}$ at $95^{\circ} \mathrm{C}$ followed by 35 cycles of $45 \mathrm{~s}$ at $95^{\circ} \mathrm{C}, 45 \mathrm{~s}$ at $50^{\circ} \mathrm{C}$, and $45 \mathrm{~s}$ at $72^{\circ} \mathrm{C}$, with a final extension of $5 \mathrm{~min}$ at $72^{\circ} \mathrm{C}$. The reactions were carried out in a Veriti thermocycler (Applied Biosystems, Carlsbad, CA, USA).

The second round of amplifications were performed in two separate assays: assay 1 , containing primers CLU, CTR, CALB, and CGL at concentrations of $0.1 \mu \mathrm{M}$, $0.12 \mu \mathrm{M}, 0.2 \mu \mathrm{M}$, and $0.3 \mu \mathrm{M}$, respectively; and assay 2 , containing primers CKR, CPAR, and CPEL at concentrations of $0.2 \mu \mathrm{M}, 0.15 \mu \mathrm{M}$, and $0.12 \mu \mathrm{M}$, respectively. In both assays, $2 \mu \mathrm{L}$ of a 1:100 dilution of the ITS PCR product was used as the DNA template. This template was mixed with the inner primers and 5\% dimethyl sulfoxide (Merck, Darmstadt, Germany) to fresh reaction mixtures in a total volume of $25 \mu \mathrm{L}$. The amplifications were carried out in the same thermocycler under the following conditions: an initial denaturation step of $5 \mathrm{~min}$ at $95^{\circ} \mathrm{C}, 10 \mathrm{cy}$ cles of $45 \mathrm{~s}$ at $95^{\circ} \mathrm{C}, 45 \mathrm{~s}$ at $67-58^{\circ} \mathrm{C}$ (touchdown), and $45 \mathrm{~s}$ at $72^{\circ} \mathrm{C}$ followed by 20 cycles of $45 \mathrm{~s}$ at $95^{\circ} \mathrm{C}, 45 \mathrm{~s}$ at $58^{\circ} \mathrm{C}$, and $45 \mathrm{~s}$ at $72^{\circ} \mathrm{C}$, with a final extension of $5 \mathrm{~min}$ at $72^{\circ} \mathrm{C}$.

In all experiments, negative controls containing sterile water instead of genomic DNA and positive controls containing Candida DNA were tested.

The nested PCR products were detected on 2.5\% agarose gels stained with GelRed ${ }^{\mathrm{Tm}}$ (Biotium, Hayward, CA, USA) and visualised under a UV transilluminator apparatus (UVITEC, Cambridge, UK).

\section{Multiplex nested PCR detection limit and specificity}

To determine the detection limit for Candida DNA in clinical specimens, nested amplifications were performed with genomic DNA extracted from $1 \mathrm{~mL}$ of a blood sample obtained from a healthy subject spiked with the seven Candida species DNA ranging from 1.5 ng to $15 \mathrm{fg}$ (one Candida genome corresponds to approximately $37 \mathrm{fg}$ of DNA). Each of the Candida species was tested separately [21].

The PCR specificity was evaluated by testing DNA samples from microorganisms that are common etiologic agents of neonatal and paediatric sepsis, such as Staphylococcus aureus, S. epidermidis, Streptococcus pyogenes, Escherichia coli, Enterococcus faecalis, and Pseudomonas aeruginosa. The DNA samples of other Candida species such as C. guilliermondii, C. kefyr, C. famata, C. dubliniensis and $C$. haemulonii, as well as some non-Candida fungi 
(Cryptococcus sp., Trichosporon sp., Rhodotorula sp., Aspergillus sp., and Fusarium sp.) were also tested.

\section{Sequencing of the PCR products}

To certify that the amplified products corresponded to Candida sequences, the PCR products generated from the blood samples that yielded negative blood cultures were sequenced on an ABI 3730 DNA apparatus (Applied Biosystems). Sequence alignments were performed with ClustalW2, and the nucleotide sequence consensus was compared with those of other Candida strains available in GenBank using the BLAST tool.

\section{Statistical analysis}

Statistical analysis of the results was carried out with SPSS software (13.0). The McNemar test was employed.

\section{Results}

The detection limit of the multiplex nested PCR for the seven tested Candida species was $150 \mathrm{fg}$, or the equivalent of four Candida genomes/mL of blood. Regarding the specificity, the bacteria, other Candida species and non-Candida fungi did not produce any amplification products.

Among the 54 enrolled patients, 32 were males and 22 were females, with ages ranging from six days to 16 years. All patients had central venous catheters and had received broad-spectrum antibiotics for more than 96 hours at the time of blood sampling. Subsequently to the blood collections, 38 patients (70.4\%) initiated presumptive antifungal therapy due to the suspicion of fungal infection.

Blood from eight patients yielded positive cultures (14.8\%), while Candida DNA was detected in 13 patients $(24.0 \%)$ by the molecular assay, including the eight patients with positive cultures (Figure 1). Demographic data, clinical conditions, and the outcomes of these 13 patients are described in Table 2. The McNemar test did not uncover a disagreement between the blood cultures and the multiplex nested PCR results $(\mathrm{p}=0.063)$.

Regarding Candida species identification, PCR was $100 \%$ concordant with blood cultures. There were five patients in whom the multiplex-nested PCR was positive and the blood cultures were negative. The amplification products were submitted to sequencing analysis and showed 99 to $100 \%$ sequence identity with the Candida reference strains (Table 2). Among these five patients, PCR was able to identify dual candidaemia (C. parapsilosis sensu stricto and $C$. tropicalis) in the blood samples of three patients with negative cultures (Table 2).

The multiplex nested PCR was consistently negative when DNA samples obtained from the control group patients were amplified. In addition, the technique allowed the release of results in 24 hours, as opposed to the mean time of 72 hours for blood cultures.

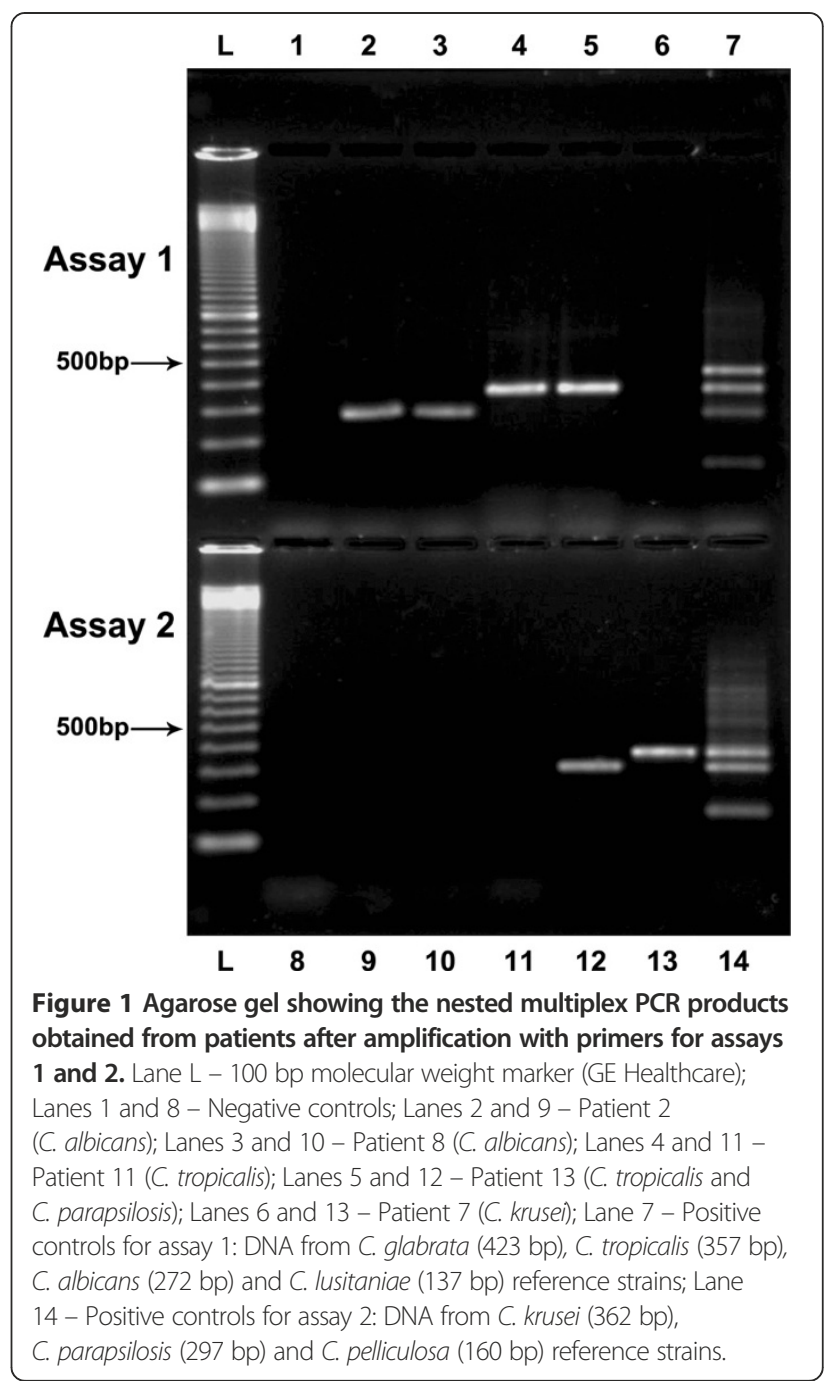

\section{Discussion and conclusions}

This study describes the development of a multiplex nested PCR method to detect and identify the seven of the most Candida species causing invasive candidiasis in the paediatric ICU setting: C. albicans, C. parapsilosis, C. tropicalis, C. glabrata, C. krusei C. lusitaniae and C. pelliculosa [22,23]. The primers designed to amplify these Candida species showed consistent and specific results (Figure 1).

Although C. lusitaniae is less frequently isolated from paediatric bloodstream infections, the clinical relevance of the identification of this species relates to its association with resistance to amphotericin B and worse clinical outcome [24]. Outbreaks of C. pelliculosa in paediatric intensive care units have already been reported in Brazil [25], reinforcing the importance of the inclusion of this Candida species in molecular investigations.

This multiplex nested PCR method reached the detection limit of four Candida genomes/mL of blood for the 
Table 2 Demographic, clinical, and laboratory data of the 13 patients with positive PCR

\begin{tabular}{|c|c|c|c|c|c|c|c|c|c|}
\hline Patients & $\mathbf{G}$ & Age & Underlying disease & BSAT & CVC & AFT & Outcome & Blood cultures & Nested PCR multiplex \\
\hline 1 & M & $19 d$ & Ichthyosis, prematurity & Yes & Yes & Yes & Died & C.parapsilosis & C. parapsilosis \\
\hline 2 & M & $14 d$ & Prematurity & Yes & Yes & Yes & Survived & C. albicans & C. albicans \\
\hline 3 & $\mathrm{~F}$ & $44 d$ & Esophageal atresia & Yes & Yes & Yes & Survived & C. albicans & C. albicans \\
\hline 4 & $\mathrm{~F}$ & $20 \mathrm{~m}$ & Acute lymphoblastic leukemia & Yes & Yes & Yes & Died & C. tropicalis & C. tropicalis \\
\hline 5 & M & $20 \mathrm{~m}$ & Non-Hodgkin lymphoma & Yes & Yes & Yes & Survived & C. albicans & C. albicans \\
\hline 6 & $\mathrm{~F}$ & $11 \mathrm{~m}$ & Hydrocephalus & Yes & Yes & Yes & Survived & C. albicans & C. albicans \\
\hline 7 & M & $5 y$ & Disseminated medullobastoma & Yes & Yes & Yes & Died & C. krusei & C. krusei \\
\hline 8 & $\mathrm{~F}$ & $16 \mathrm{~m}$ & Hydrocephalus & Yes & Yes & Yes & Died & C. albicans & C. albicans \\
\hline 9 & M & $3 y$ & Bone marrow transplantation, neuroblastoma & Yes & Yes & Yes & Died & Negative & C. tropicalis and C. parapsilosis \\
\hline 10 & $\mathrm{~F}$ & $15 y$ & Osteosarcoma, septic shock & Yes & Yes & Yes & Died & Negative & C. parapsilosis ${ }^{\mathrm{a}}$ \\
\hline 11 & M & $35 d$ & Congenital diaphragmatic hernia & Yes & Yes & Yes & Survived & Negative & C. tropicalis ${ }^{\mathrm{a}}$ \\
\hline 12 & M & $9 d$ & Congenital diaphragmatic hernia & Yes & Yes & Yes & Survived & Negative & C. tropicalis and C. parapsilosis ${ }^{\overline{2}}$ \\
\hline 13 & M & $55 d$ & Necrotizing enterocholitis & Yes & Yes & Yes & Died & Negative & C. tropicalis and C. parapsilosis \\
\hline
\end{tabular}

$\mathrm{G}=$ gender; $\mathrm{M}=$ male; $\mathrm{F}=$ female; $\mathrm{d}=$ days $\mathrm{m}=$ months $\mathrm{y}=$ years; $\mathrm{BSAT}=$ broad spectrum antibiotic therapy; $\mathrm{CVC}=$ central venous catheter; AFT = presumptive antifungal therapy after blood sample collections.

${ }^{\mathrm{a}}=$ Sequencing analysis showed $99-100 \%$ identity with C. parapsilosis stricto sensu [GenBank: JN997459.1] and 99-100\% identity with C. tropicalis [GenBank: EU266571.1].

seven investigated species, which is an excellent analytical sensitivity considering the recommendation for candidaemia diagnostic molecular tests (i.e., detection of at least $10 \mathrm{CFU} / \mathrm{mL}$ of blood) [2,26]. Tirodker et al. also compared PCR and blood cultures for Candida detection in patients in the paediatric ICU with suspected fungemia, revealing that the molecular technique had a higher positivity. However, the single-round PCR utilised by these authors could not discriminate Candida species and had a detection limit of $100 \mathrm{CFU} / 0.5 \mathrm{~mL}$ of blood [27]. Thus, the multiplex nested PCR developed in the current study was more sensitive. Cross-reactions with other organisms aside from Candida as well as nonspecific amplifications in the control group were not observed in the present study, indicating that this multiplex nested PCR method is both specific and sensitive.

Our molecular assay yielded more positive results than blood cultures (24.0\% vs. $14.8 \%$, respectively). Sequencing of the amplification products obtained from the five PCRpositive patients with negative blood cultures confirmed that the amplification products were from the expected Candida species, demonstrating the specificity of the test.

The statistical comparison between the two laboratory techniques (blood culture versus multiplex nested PCR) did not reveal a significant difference $(\mathrm{p}=0.063)$, most likely due to the restricted number of patients and samples $(n=54)$. Nevertheless, several studies have previously demonstrated that molecular techniques perform better than culture methods $[2,10,12]$.

In our study, C. albicans was the most frequently isolated species in blood cultures (five out of eight positive results), while the multiplex nested PCR identified $C$. albicans, C. parapsilosis complex, and C. tropicalis at similar frequencies (Table 2). Thus, the molecular tool allowed the identification of a range of different Candida species that cause bloodstream infections in these critically ill paediatric patients.

Dual candidaemia was detected in three patients only by the multiplex nested PCR method (C. parapsilosis sensu stricto and $C$. tropicalis). In fact, dual candidaemia has been increasingly reported with the advent of diagnostic molecular tools and may be clinically relevant in cases in which one of the detected Candida species is resistant to drugs usually employed in the antifungal therapy [11,12,28,29]. However, as reported in other studies [30,31], it was not possible to differentiate the dual candidaemia patients from those with only one Candida species with respect to the risk factors and the infection outcome, probably because of the restricted number of cases. Although C. albicans is often involved in mixed candidaemia episodes [29-31], this species was not present in these three particular cases. This may be related to the fact that in Brazil C. parapsilosis and $C$. tropicalis are the non-C. albicans species more frequently isolated from candidaemia episodes, particularly in paediatric ICU patients [32,33].

While detection of Candida DNA by the PCR assay in blood samples from patients with negative cultures can be related to transient episodes rather than true candidaemia, the finding of a positive PCR in a critically ill patient should be strongly considered due to the high potential of this eventually transient episode to rapidly turn into a systemic infection. On the other hand, the fact that our multiplex PCR assay was negative in all 28 control children, strongly suggests that this assay can be useful, in association with appropriate clinical evaluation, to rule out the presence of candidaemia and interrupt unnecessary 
antifungal therapy [34]. Studies with higher number of patients are necessary to determine precisely its negative predictive value.

Our multiplex nested PCR method showed other important advantages. The time to PCR results was 24 hours, while the mean time to release blood culture results was 72 hours, ranging from 48 to 96 hours considering the patients in this study. The ability to detect infection early and discriminate Candida species is extremely important for planning the introduction of antifungal therapy, thus improving the outcome of infected patients and reducing the hospitalisation costs [11]. In addition this assay allows for the detection of Candida in small volumes of blood, which is an advantage for ICU neonates and younger children [6]. However, this study was designed such that equal volumes of blood were used to perform cultures and PCR (1-2 mL) to ensure that the results were comparable.

An intrinsic limitation of studies designed to validate molecular diagnostic tools for Candida infections is that the gold standard method-blood culture-is a technique that lacks sensitivity [2]. Other tests that could eventually be used to confirm the molecular results, such as the $\beta-1,3$ glucan and mannan tests, also lack sensitivity and specificity $[35,36]$.

Novel technologies have recently been exploited for rapid detection and identification of Candida species in bloodstream infections. Some assays based on real- time platforms have also been developed to detect candidaemia, though some limitations of sensitivity and specificity were observed [36,37]. A recently described magnetic resonancebased technology (T2Candida ${ }^{\circ}$ ) seems to be able to detect low concentrations of Candida in whole blood samples (as low as one $\mathrm{CFU} / \mathrm{mL}$ ) in less than two hours [38]. However, further investigations are still required for validation of both methodologies in the clinical and laboratory settings.

We proposed a multiplex PCR assay targeting the ITS region of Candida ribosomal DNA able to identify the main Candida species involved in bloodstream paediatric infections with a detection limit of less than $10 \mathrm{CFU} / \mathrm{mL}$, high specificity, and as least as sensitive as blood cultures but with a shorter turnaround time. Use of the multiplex nested PCR method also allowed the detection and identification of one or more Candida species in the same reaction.

\section{Abbreviations \\ PCR: Polymerase chain reaction; ICU: Intensive care unit; SIRS: Systemic inflammatory response syndrome; ATCC: American Type Culture Collection; ITS: Intergenic space region of ribosomal DNA; dNTP: Deoxynucleotide triphosphate; $\mathrm{MgCl}_{2}$ : Magnesium chloride.}

\section{Competing interests}

The authors declare that they have no competing interests.

\section{Authors' contributions}

CLT contributed on the conception of the study, carried out the molecular techniques, participated in acquisition, analysis and interpretation of data, and drafted the manuscript. TSO contributed on the study design and critically revised the manuscript. AFD, MEJRC and MTGA participated in patients recruitment and acquisition of data. GMBDN coordinated the study design, contributed to the analysis and interpretation of data, and critically revised the manuscript. All authors read and approved the final version of the manuscript.

\section{Acknowledgements}

Dr. Antonio José Gonçalves Leal from the Pediatric Surgery Division, Instituto da Criança - HCFMUSP for providing blood samples from the control group. Angela Midori Matuhara from the Intensive Care Unit, Instituto da Criança HCFMUSP for clinical support in selecting patients for samples collection. Dr. Gil Benard for critically reviewing the manuscript.

\section{Financial support}

This study was supported by grants from Fundação de Amparo à Pesquisa do Estado de São Paulo - FAPESP 2010/02626-6 and FAPESP 2010/09715-4.

\section{Author details}

${ }^{1}$ Laboratory of Medical Mycology (LIM-53), Clinical Dermartology Division, Hospital das Clínicas da Faculdade de Medicina da Universidade de São Paulo (HCFMUSP) and Instituto de Medicina Tropical da Universidade de São Paulo (IMT-USP), Av. Dr. Enéas Carvalho de Aguiar, 500, Andar térreo, Predio 2, CEP, 05403-900 São Paulo, SP, Brazil. 'Laboratory of Seroepidemiology and Immunobiology, IMT-USP, São Paulo, SP, Brazil. ${ }^{3}$ Pediatric and Neonatal Intensive Care Units, Instituto da Criança, HCFMUSP, São Paulo, SP, Brazil. ${ }^{4}$ Microbiology Laboratory, Department of Dermatologic, Infectious and Parasitic Diseases, Faculdade de Medicina de São José do Rio Preto (FAMERP), São José do Rio Preto, SP, Brazil.

Received: 21 March 2014 Accepted: 10 July 2014

Published: 21 July 2014

\section{References}

1. Arendrup MC: Epidemiology of invasive candidiasis. Curr Opin Crit Care 2010, 16(5):445-452.

2. Avni T, Leibovici L, Paul M: PCR diagnosis of invasive candidiasis: systematic review and meta-analysis. J Clin Microbiol 2011, 49(2):665-670.

3. Benjamin DK Jr, Poole C, Steinbach WJ, Rowen JL, Walsh TJ: Neonatal candidemia and end-organ damage: a critical appraisal of the literature using meta-analytic techniques. Pediatrics 2003, 112(3 Pt1):634-640.

4. Wisplinghoff $H$, Bischoff T, Tallent SM, Seifert $H$, Wenzel RP, Edmond MB: Nosocomial bloodstream infections in US hospitals: analysis of 24,179 cases from a prospective nationwide surveillance study. Clin Infect Dis 2004, 39:309-317.

5. Zaoutis TE, Prasad PA, Localio AR, Coffin SE, Bell LM, Walsh TJ, Gross R: Risk factors and predictors for candidemia in pediatric intensive care unit patients: implications for prevention. Clin Infect Dis 2010, 51(5):e38-e45.

6. Kaufman DA: Challenging issues in neonatal candidiasis. Curr Med Res Opin 2010, 26(7):1769-1778.

7. Chai ALY, Denning DW, Warn P: Candida tropicalis in human disease Crit Rev Microbiol 2010, 36(4):282-298.

8. Nucci M, Queiroz-Telles F, Alvarado-Matute T, Tiraboschi IN, Cortes J, Zurita J, Guzman-Blanco M, Santolaya ME, Thompson L, Sifuentes-Osornio J, Echevarria Jl, Colombo AL: Epidemiology of candidemia in Latin America: a laboratory-based survey. PLoS One 2013, 8(3):e59373.

9. See LLC: Bloodstream infection in children. Pediatr Crit Care Med 2005, 6:S42-44.

10. Lau A, Sorrell TC, Chen S, Stanley K, Iredell J, Halliday C: Multiplex tandem PCR: a novel platform for rapid detection and identification of fungal pathogens from blood culture specimens. J Clin Microbiol 2008, 46(9):3021-3027.

11. Zilberberg MD, Kollef MH, Arnold H, Labelle A, Micek ST, Kothari S, Shorr AF: Inappropriate empiric antifungal therapy for candidemia in the ICU and hospital resource utilization: a retrospective cohort study. BMC Infect Dis 2010, 10:150.

12. Ahmad S, Khan Z, Mustafa AS, Khan ZU: Seminested PCR for diagnosis of candidemia: comparison with culture, antigen detection, and biochemical methods for species identification. J Clin Microbiol 2002, 40:2483-2489. 
13. Alam FF, Mustafa AS, Khan ZU: Comparative evaluation of (1,3)- $\beta$-D-glucan, mannan and anti-mannan antibodies, and Candida species-specific SnPCR in patients with candidemia. BMC Infect Dis 2007, 7:103-111.

14. Carvalho A, Costa-De-Oliveira S, Martins ML, Pina-Vaz C, Rodrigues AG, Ludovico P, Rodrigues F: Multiplex PCR identification of eight clinically relevant Candida species. Med Mycol 2007, 45:619-627.

15. Goldstein B, Giroir B, Randolph A: International pediatric sepsis consensus conference: definitions for sepsis and organ dysfunction in pediatrics. Pediatr Crit Care Med 2005, 6(1):2-8.

16. Löffler J, Hebart H, Schumacher U, Reitze H, Einsele H: Comparison of different methods for extraction of DNA of fungal pathogens from cultures and blood. J Clin Microbiol 1997, 35:3311-3312.

17. Van Burik J, Myerson D, Schreckhise RW, Bowden R: Panfungal PCR assay for detection of fungal infection in human blood specimens. J Clin Microbiol 1998, 36:1169-1175.

18. Luo G, Mitchell TG: Rapid identification of pathogenic fungi directly from cultures by using multiplex PCR. J Clin Microbiol 2002, 40:2860-2865.

19. Bougnoux M, Dupont C, Mateo J, Saulnier P, Faivre V, Payen D, Nicolas Chanoine M: Serum is more suitable than whole blood for diagnosis of systemic candidiasis by nested PCR. J Clin Microbiol 1999, 37:925-930.

20. Rolfs A, Schuller I, Finckh U, Weber-Rolfs I: PCR contamination and falsely interpreted results. In PCR: clinical diagnostics and research. Berlin: Springer; 1992:61-67.

21. Riggsby WS, Torres-Bauza LJ, Wills JW, Townes TM: DNA content, kinetic complexity, and the ploid question in Candida albicans. Mol Cell Biol 1982, 2:853-862

22. Colombo AL, Nucci M, Park BJ, Nouér SA, Arthington-Skaggs B, da Matta DA, Warnock D, Morgan J, Brazilian Network Candidemia Study: Epidemiology of candidemia in Brazil: a nationwide sentinel surveillance of candidemia in eleven medical centers. J Clin Microbiol 2006, 44(8):2816-2833.

23. Pfaller MA, Diekema DJ: Epidemiology of invasive candidiasis: a persistent public health problem. Clin Microbiol Rev 2007, 20:133-163.

24. Blinkhorn RJ, Adelstein D, Spagnuolo PJ: Emergence of a new opportunistic pathogen: Candida lusitaniae. J Clin Microbiol 1989, 27(2):236-240

25. Aragão PA, Oshiro IC, Manrique El, Gomes CC, Matsuo LL, Leone C, MorettiBranchini ML, Levin AS, IRIS Study Group: Pichia anomala outbreak in a nursery: exogenous source? Pediatr Infect Dis J 2001, 20(9):843-848.

26. White PL, Barton R, Guiver M, Linton CJ, Wilson S, Smith M, Gomez BL, Carr MJ, Kimmitt PT, Seaton S, Rajakumar K, Holyoake T, Kibbler CC, Johnson E, Hobson RP, Jones B, Barnes RA: A consensus on fungal polymerase chain reaction diagnosis? A United Kingdom-Ireland evaluation of polymerase chain reaction methods for detection of systemic fungal infections. J Molec Diagn 2006, 8(3):376-384

27. Tirodker UH, Nataro JP, Smith S, LasCasas L, Fairchild KD: Detection of fungemia by polymerase chain reaction in critically ill neonates and children. J Perinatol 2003, 23(2):117-122.

28. Del Negro GM, Delgado AF, Manuli ER, Yamamoto L, Okay TS: Dual candidemia detected by nested polymerase chain reaction in two critically ill children. Med Mycol 2010, 48(8):1116-1120.

29. Boktour M, Kontoyiannis DP, Hanna HA, Hachem RY, Girgawy E, Bodey GP, Raad II: Multiple-species candidemia in patients with cancer. Cancer 2004, 101(8):1860-1865.

30. Jensen J, Muñoz P, Guinea J, Rodríguez-Créixems M, Peláez T, Bouza E: Mixed fungemia: incidence, risk factors, and mortality in a general hospital. Clin Infect Dis 2007, 44(12):e109-114.

31. Pulimood S, Ganesan L, Alangaden G, Chandrasekar P: Polymicrobial candidemia. Diagn Microbiol Infect Dis 2002, 44(4):353-357.

32. Colombo AL, Guimarães T, Camargo LF, Richtmann R, Queiroz-Telles FD, Salles MJ, Cunha CA, Yasuda MA, Moretti ML, Nucci M: Brazilian guidelines for the management of candidiasis - a joint meeting report of three medical societies: Sociedade Brasileira de Infectologia, Sociedade Paulista de Infectologia and Sociedade Brasileira de Medicina Tropical. Braz J Infect Dis 2013, 17(3):283-312.

33. Santolaya ME, Alvarado T, Queiroz-Telles F, Colombo AL, Zurita J, Tirabosch IN, Cortes JA, Thompson L, Guzman M, Sifuentes J, Echevarría Jl, Nucci M: Active surveillance of candidemia in children from Latin America: a key requirement for improving disease outcome. Pediatr Infect Dis J 2014. 33(2):e40-44.
34. Clancy CJ, Nguyen MH: Finding the "missing 50\%" of invasive candidiasis: how nonculture diagnostics will improve understanding of disease spectrum and transform patient care. Clin Infect Dis 2013, 56(9):1284-1292.

35. Montagna MT, Caggiano G, Borghi E, Morace G: The role of the laboratory in the diagnosis of invasive candidiasis. Drugs 2009, 69(Suppl 1):59-63.

36. Nguyen MH, Wissel MC, Shields RK, Salomoni MA, Hao B, Press EG, Shields RM, Cheng S, Mitsani D, Vadnerkar A, Silveira FP, Kleiboeker SB, Clancy CJ: Performance of Candida real-time polymerase chain reaction, $\beta$-D-glucan assay, and blood cultures in the diagnosis of invasive candidiasis. Clin Infect Dis 2012, 54(9):1240-1248.

37. Neely LA, Audeh M, Phung NA, Min M, Suchocki A, Plourde D, Blanco M, Demas V, Skewis LR, Anagnostou T, Coleman JJ, Wellman P, Mylonakis E, Lowery TJ: T2 magnetic resonance enables nanoparticle-mediated rapid detection of candidemia in whole blood. Sci Transl Med 2013, 5(182):182ra54.

38. Lau A, Halliday C, Chen SC, Playford EG, Stanley K, Sorrell TC: Comparison of whole blood, serum, and plasma for early detection of candidemia by multiplex-tandem PCR. J Clin Microbiol 2010, 48(3):811-816.

doi:10.1186/1471-2334-14-406

Cite this article as: Taira et al: A multiplex nested PCR for the detection and identification of Candida species in blood samples of critically ill paediatric patients. BMC Infectious Diseases 2014 14:406.

\section{Submit your next manuscript to BioMed Central and take full advantage of:}

- Convenient online submission

- Thorough peer review

- No space constraints or color figure charges

- Immediate publication on acceptance

- Inclusion in PubMed, CAS, Scopus and Google Scholar

- Research which is freely available for redistribution

Submit your manuscript at www.biomedcentral.com/submit
C BioMed Central 